\title{
Characterization of the TNFR1-d2 protein: Implication in TNF receptor associated periodic syndrome (TRAPS)?
}

\author{
C Rittore ${ }^{1,2^{*}}$, E Sanchez ${ }^{2,3}$, S Soler ${ }^{4}$, V Ea ${ }^{5,6}$, D Genevieve ${ }^{2,3,6}$, I Touitou ${ }^{1,2,6}$, S Grandemange ${ }^{1,2}$ \\ From 8th International Congress of Familial Mediterranean Fever and Systemic Autoinflammatory Diseases \\ Dresden, Germany. 30 September - 3 October 2015
}

\section{Introduction}

Binding of TNF to TNF receptor 1 (TNFR1) induces both the survival pathway by activation of the NF-kB transcription factor, and the death pathway by apoptosis. Mutations in the TNFR1 gene (TNFSFR1A) are responsible for the auto-inflammatory disease TRAPS, a dominantly inherited hereditary recurrent fever. Various defects such as defective TNFR1 receptor shedding, protein misfolding, NF-kB activation, or apoptosis have been associated with the pathogenesis of TRAPS.

Previously, we have identified TNFR1-d2, an exon2spliced transcript of TNFRSF1A. TNFR1-d2 is expressed in a tissue-specific manner in contrast to ubiquitous expression of the full-length TNFR1 transcript.

\section{Objectives}

This study aimed to analyze the TNFR1-d2 protein expression and its function in NF-kB signalling pathways and to investigate the possible role of TNFR1-d2 in TRAPS physiopathology.

\section{Materials and methods}

Translation analyses of TNFR1-d2 were performed in HEK293T by over-expression of different TNFR1-d2 cDNA constructs fused to the Flag tag. HEK293T transfected cells were used to measure internal ribosome entry site (IRES) activity and NF- $\kappa \mathrm{B}$-activation by luciferase assays. Subcellular localization of the TNFR1-d2 fused to the GFP protein was studied in MCF7 cells, followed by staining of different cellular compartments and confocal fluorescence microscopy analysis.

'Laboratoire des maladies rares et auto-inflammatoires, Hopital A. de Villeneuve, Montpellier, France

Full list of author information is available at the end of the article

\section{Results}

We showed that TNFR1-d2 is translated from an alternative start codon due to an IRES activity created by the exons 1 and 3 junction. The methionine 109 located in exon 4 in-frame with TNFR1 was used, resulting in a putative new protein isoform lacking its $\mathrm{N}$-terminal region. Subcellular localization showed that the full-length and TNFR1-d2 proteins shared the same intracellular localization to the Golgi complex. Since the c.224C>T (p.Pro75Leu, P46L) and c.236C > T (p.Thr79Met, T50M) mutations in exon 3 lie in close vicinity to a strong Kozak consensus sequence, we hypothesized that these 2 sequence variants could affect TNFR1-d2 translation. Interestingly, we found that only TNFR1-d2 carrying the severe T50M mutation was translated through the mutated codon which induced a decrease of the IRES activity. Moreover, whereas overexpression of wild type TNFR1-d2 was not associated with increased NF- $\kappa \mathrm{B}$ transcriptional activity, TNFR1-d2T50M seemed to increase NF- $\kappa \mathrm{B}$ activity as compared to the empty vector.

\section{Conclusion}

Our results support that the TNFR1-d2-T50M translation defect could lead to a gain-of-function of TNFR1-d2, suggesting that TNFR1-d2 may account for the physiopathology of TRAPS in patients carrying the T50M mutation, which is associated with a severe TRAPS phenotype.

\footnotetext{
Authors' details

${ }^{1}$ Laboratoire des maladies rares et auto-inflammatoires, Hopital A. de Villeneuve, Montpellier, France. ${ }^{2}$ Inserm / Chu, U1183, Montpellier, France. ${ }^{3}$ Département de génétique médicale, Hopital A. de Villeneuve, Montpellier, France. ${ }^{4} \mathrm{CHU}$ Caremeau, Pole psychiatrie, Nimes, France. ${ }^{5}$ Institut de génétique moléculaire, Montpellier, France. ${ }^{6}$ Université, Montpellier, France.
}

Published: 28 September 2015 
doi:10.1186/1546-0096-13-S1-P39

Cite this article as: Rittore et al:: Characterization of the TNFR1-d2

protein: Implication in TNF receptor associated periodic syndrome

(TRAPS)? Pediatric Rheumatology 2015 13(Suppl 1):P39.

Submit your next manuscript to BioMed Central and take full advantage of:

- Convenient online submission

- Thorough peer review

- No space constraints or color figure charges

- Immediate publication on acceptance

- Inclusion in PubMed, CAS, Scopus and Google Scholar

- Research which is freely available for redistribution

Submit your manuscript at www.biomedcentral.com/submit 